COUNSENESIA
Indonesian Journal of Guidance and Counseling
www.ejournal.utp.ac.id /index.php/CIJGC

\title{
KESADARAN DIRI DAN KEDISIPLINAN BELAJAR PADA SISWA SMA
}

\author{
Saroji ${ }^{1}$, Neni Widyayanti ${ }^{2}$ Roy Gustaf Tupen Ama $^{3}$ \\ ${ }^{1,2,3}$ Sekolah Tinggi Psikologi Yogyakarta, Indonesia \\ Email: rovama27@gmail.com
}

\begin{tabular}{l}
\hline Info Artikel \\
\hline Riwayat Artikel \\
Diterima: \\
12 Maret 2021 \\
Disetujui: \\
29 Maret 2021 \\
Publikasi: \\
Juni 2021 \\
\hline
\end{tabular}

\begin{abstract}
Abstrak
Tujuan dari penelitian ini adalah untuk mengetahui hubungan kesadaran diri dengan kedisiplinan belajar pada siswa SMK "X" Magelang. Subjek dari penelitian ini adalah Siswa Kelas XI SMK “X” Magelang dengan jumlah sampel sebanyak 119 subjek. Teknik pengambilan sampel menggunakan teknik cluster random sampling. Pengumpulan data penelitian dilakukan dengan menggunakan skala kedisiplin belajar dan skala kesadaran diri. Instrumen penelitian skala disiplin belajar $(\alpha)=0,942$ dengan 41 item valid dan kesadaran diri $(\alpha)=0,921$ dengan 41 item valid. Teknik analisa data yang digunakan adalah pearson product moment. Hasil penelitian menunjukan bahwa ada hubungan positif yang signifikan antara kesadaran diri dengan kedisiplinan belajar pada siswa SMK "X" Magelang dengan nilai (rxy) sebesar 0,760, taraf signifikansi sebesar 0,000 $(\mathrm{p}<0,05)$. Sumbangan efektif kesadaran diri terhadap kedisiplinan belajar adalah sebesar 57,7\%. Sampel penelitian memiliki kesadaran diri dengan kategori sedang sebesar 70,6\% dan kedisiplinan belajar dengan kategori sedang sebesar $63,9 \%$.
\end{abstract}

Kata Kunci: kesadaran diri, kedisiplinan belajar, siswa

\begin{abstract}
The purpose of this study was to determine the relationship between self-awareness and learning of discipline in students of SMK "X" Magelang. The subjects of this study were students of class XI SMK "X" Magelang with a total sample of 119 subjects. The sampling technique was using cluster random sampling technique. Research data collection was carried out using a scale of learning discipline and a scale of selfawareness. The learning of discipline scale research instrument $(\alpha)=0.942$ with 41 valid items and self-awareness $(\alpha)=0.921$ with 41 valid items. The data analysis technique used is the Pearson product moment. The results showed that there was a significant positive relationship between self-awareness and learning discipline in students of SMK " $X$ " Magelang with a value (rxy) of 0.760, a significance level of 0.000 ( $p<0.05)$. The effective contribution of self-awareness to critical thinking skills is $57.7 \%$. The research sample has self-awareness with a moderate category of $70.6 \%$ and a discipline learning discipline with a moderate category of $63.9 \%$.
\end{abstract}

Keywords: Self Awareness, Learning of Dicipline, students

(C) 2021 Universitas Tunas Pembangun Surakarta

ISSN: 2746-3532 (Online) 


\section{PENDAHULUAN}

Tujuan pendidikan nasional juga dikuatkan dengan UU No. 20 tahun 2002 tentang Sistem Pendidikan Nasional pasal 1 ayat 1 yang menyatakan bahwa Pendidikan adalah usaha sadar dan terencana untuk mewujudkan suasana belajar dan proses pembelajaran agar peserta didik secara aktif mengembangkan potensi dirinya untuk memiliki kekuatan spritual keagamaan, pengendalian diri, kepribadian, kecerdasan, akhlak mulia, serta keterampilan yang diperlukan dirinya, masyarakat, bangsa dan negara.

Sarwono (2012) menyatakan bahwa sekolah merupakan lingkungan pendidikan sekunder. Hal ini dikarenakan sekolah merupakan tempat kedua setelah rumah di mana anak menghabiskan waktunya dan memperoleh pendidikan. Sebagai lembaga formal pelaksana pendidikan, sama halnya dengan keluarga, sekolah juga mengajarkan nilai-nilai dan norma-norma yang berlaku dalam masyarakat disamping mengajarkan berbagai keterampilan dan kepandaian pada siswanya. Hasil dari proses penanaman nilai dan norma pada siswa tersebut dapat dilihat pada perilakunya khususnya dalam hal kedisiplinan belajar.

Menurut Nawawi (2012) mendefenisikan kedisiplinan belajar sebagai usaha untuk membina kesadaran dalam belajar dengan baik dalam arti setiap individu wajib menjalankan fungsinya secara aktif. Menurut Winkel dan Hastuti (2004) indikator kedisiplin belajar dalam katagori tinggi mencakup beberapa unsur sebagai berikut: hadir di ruang kelas tepat pada waktunya, mentaati tata tertib di sekolah, mengikuti kegiatan ekstrakurikuler, dan belajar di rumah. Kedisiplinan belajar harus terus ditingkatkan, namun pada kenyataannya masih banyak siswa yang belum memiliki kesadaran akan pentingnya kedisiplinan belajar dalam penerapannya di sekolah.

Hasil wawancara di SMK "X" Magelang pada 6 siswa yang masing-masing mewakili dari 3 mereka mengatakan bahwa masih banyak siswa yang melakukan pelanggaran atau ketidak disiplinan belajar saat sekolah. Menurut salah satu siswa menurutnya saat pagi ada beberapa yang datang terlambat masuk kelas, membolos, berpakaian tidak rapi, tidak melaksanakan piket harian, dan saat jam pelajaran, beberapa ada yang ramai sendiri, sebagian siswa tidak memiliki tanggung jawab dengan tugas-tugas rumah (PR), mencontek pekerjan rumah (PR) punya teman. Banyak upaya yang sudah dilakukan oleh pihak sekolah dengan memberi hukuman baik hukuman berat maupun ringan, serta diberi surat peringatan (SP).

Hal ini diperkuat juga dengan hasil wawancara yang peneliti lakukan dengan guru BK bahwa masih banyak siswa yang melanggar peraturan seperti membolos, datang tidak tepat waktu, bahkan ada lagi yang ketika datang hanya absen, setelah itu pulang, yang paling sering dilakukan adalah datang tidak tepat waktu, membolos, mencontek pekerjan rumah (PR) temannya. Dari pihak sekolah menurutnya telah memberi ketegasan terhadap siswa yang melanggar serta melakukan konseling yang sudah terjadwal dengan Guru BK terkait permasalahan tersebut.

Siswa diharapkan memiliki kedisiplinan belajar yang tinggi. Kedisiplinan belajar yang tinggi akan sangat bermanfaat terhadap kesuksesan hasil belajar serta prestasi belajar siswa yang tinggi. Sukmasa (2016) dalam penelitiannya mengungkpkan bahwa dengan adanya kedisiplinan belajar yang dimiliki siswa maka hasil belajar siswa jauh lebih baik karena siswa sadar akan pentingnya disiplin belajar guna mencapai hasil belajar yang memuaskan.

Perilaku kedisiplin belajar dapat dipengaruhi oleh beberapa faktor yaitu, kesadaran diri (self awareness), pengikutan dan ketaatan, alat pendidikan, dan hukuman, mengemukakan bahwa kedisiplinan belajar, dapat menata kehidupan bersama, 
membangun kepribadian, melatih kepribadian yang baik, pemaksaan diri, hukuman, menciptakan lingkungan yang kondusif (Tu'u, 2004). Pada penelitian ini peneliti memilih faktor kesadaran diri sebagai variabel bebas. Caplin (2011) mengemukakan bahwa kesadaran diri atau self-awareness adalah wawasan ke dalam atau wawasan mengenai alasan-alasan dari tingkah laku sendiri atau pemahaman diri sendiri. Kesadaran diri juga menjadi titik tolak bagi perkembangan pribadi. Kesadaran atau self-awareness adalah bahan baku yang penting untuk menunjukkan kejelasan dan pemahaman tentang perilaku seseorang (Uno, 2008). Kesadaran diri yang tinggi dapat dilihat dari seberapa jauh individu dapat mengenali dirinya sendiri dalam emosi, pengakuan diri yang akurat serta kepercayaan diri (Goleman, 2016).

Kesadaran diri berhubungan dan berpengaruh dalam membentuk kedisiplinan siswa, untuk menciptakan suatu kondisi yang disiplin dalam belajar maka dibentuklah suatu hukuman. Hukuman yang dimaksud adalah bentuk hukuman positif dan bukan hukuman negatif yang diterapkan. Pemberian hukuman positif dalam konteks kedisiplian belajar bahwa agar siswa bisa lebih sadar untuk meningkatkan kedisplinan misalnya bagi siswa yang pernah melakukan tindak ketidakdisiplinan akan diberikan pemahaman atau pendidikan karakter, diberikan konseling baik individu dan kelompok, diberikan tugas atau pekerjaan rumah, sehingga secara tidak langsung akan meningkatkan kesadaran diri serta berpengaruh terhadap kedisiplinan siswa dalam belajar. Sehingga ada hubungan positif antara keasaran diri dengan kedisiplinan belajar siswa (Ardi,2012; Musungu \& PDGE, 2014).

Penelitian ini memilki urgensi bawasannya berdasarkan fenomena yang dijelaskan sebelumnya bahwa kedisiplinan belajar perlu di perhatikan dan dibentuk menjadi sebuah kebiasaan yang baik dalam membentuk karakter siswa sebagai generasi muda dan membentuk kedisiplian harus dimulai dari diri sendiri dengan penuh kesadarandari dalam diri. Penelitian ini berbeda dari penelitian sebelumnya dimana penelitian ini mengkaji kedisiplinan belajar dari faktor psikologis yaitu kesadaran diri, pada penelitian sebelumnya sebagian besar mengkaji dari faktor ekternal seperti peran dan fungsi sekolah, metode belajar dan peraturan yang diterapkan baik di sekolah dan lingkungan keluarga.

Tujuan dari penelitian ini untuk mengetahui hubungan antara kesadaran diri dengan kedisiplinan belajar siswa SMK X Magelang. Adapun implikasi dari peneltian ini adalah memberikan sumbangan dalam ilmu-ilmu pendidikan misalnya psikologi pendidikan, konseling pendidikan serta menjadi rujuakan bagi guru, orangtua dan sekolah dalam meningkatkan kedisiplinan belajar siswa. Hipotesis yang diajukan dalam penelitian ini adalah: "ada hubungan positif antara kedisiplinan belajar dengan kesadaran diri". Semakin tinggi kesadaran diri maka kedisiplinan belajar siswa semakin tinggi. Sebaliknya semakin rendah kesadaran diri maka kedisiplinan belajar siswa semakin rendah

\section{METODE}

Jenis penelitian ini adalah penelitian kuantitatif korelasional. Sampel penelitian adalah siswa siswi kelas XI dengan jumlah 119 kelas A,B, C, dan D. Teknik pengambilan sampel menggunakan simpel random sampling. Metode pengumpulan data menggunakan skala disiplin belajar dan skala kesadaran diri. Sebelum dilaksanakan penelitian terlebih dahulu kedua skala tersebut diujicobakan kepada 88 respoden berumur 16- 18 tahun. Skala kedisiplinan belajar terdiri dari 44 aitem. Setelah dilakukan uji coba, terdapat 41 aitem yang sahih dengan koefisien korelasi aitem $\geq 0.250$ yang bergerak dari 0.303 sampai 0.740 dengan nilai reliabilitas sebesar 0,934. Skala kesadaran diri terdiri dari 60 
aitem pada saat akan dilakukan uji coba. Setelah dilakukan uji coba, terdapat 41 aitem yang sahih dengan koefisien aitem $\geq 0.250$ yang bergerak dari 0.266 sampai 0.647 dengan nilai reliabilitas sebesar 0,902 . Teknik analisis data yang digunakan adalah analis korelasi product moment untuk melihat hubungan variabel independengan dengan dependen. Alasan menurunkan daya diskriminasi aitem dengan standar 0,25 adalah untuk menghindari banyak aitem yang gugur serta agar setiap aspek-aspek dan indikator terwakilkan. Dalam pengukuran psikologis batas standar uji daya beda aitem 0,30 namun kriteria ini tidak menjadi patokan tunggal dalam menentukan aitem-aitem yang valid sebagai bagian dari tes karena harus memperhatikan isi domain yang diungkap, tujuan penggunaan hasil test serta aitem-aitem dipastikan mewakili apa yang ingin diungkap sehingga dengan pertimbangan tersebut batasan koreksi bisa diturunkan menjadi 0,25. (Azwar, 2016).

Kedua instrumen yaitu skala kesadaran diri dan kedisiplinan belajar pada penelitian ini diukur menggunakan model sistem mengacu pada skoring model likert yang disusun dengan konsep (favorable) dan (unfavorable). Pada setiap pernyataan teridri dari empat alternatif pilihan jawaban, yaitu Sangat Setuju (SS), Setuju (S), Tidak Setuju (TS), Sangat Tidak Setuju (STS). Pada item favorable diberi skor 4 untuk jawaban SS (Sangat Setuju), nilai 3 untuk jawaban (S) Setuju, nilai 2 untuk jawaban Tidak Setuju (TS), dan nilai 1 untuk jawaban Sangat Tidak Setuju (STS). Sedangkan pada item yang tidak mendukung (unfavorable), skor diberikan sebaliknya yaitu skor 1 untuk nilai untuk SS (Sangat Setuju), nilai 2 untuk (S) Setuju, nilai 3 untuk Tidak Setuju (TS), dan nilai 4 untuk Sangat Tidak Setuju (STS).

\section{HASIL DAN PEMBAHASAN}

Hasil Pengumpulan data kemudian disajikan sebagai gambaran umum/deskripsi singkat mengenai penelitian yang berisikan deskripsi data berdasarkan jenis kelamin subjek penelitian, diantaranya skor mean dan standar deviasi dari masing-masing jenis kelamin yang disajikan pada tabel dibawah ini.

Tabel 1. Deskripsi Data Berdasarkan Jenis Kelamin

\begin{tabular}{lcccr}
\hline Kategori variable & $\begin{array}{c}\text { Jenis } \\
\text { kelamin }\end{array}$ & $\mathrm{N}$ & Mean & Std.Deviation \\
\hline Kesadaran diri & Perempuan & 42 & 123,64 & 15,083 \\
\hline & Laki-laki & 77 & 114,8961 & 12,88163 \\
\hline Kedisiplinan belajar & Perempuan & 42 & 120.0238 & 14,99022 \\
\hline & Laki-laki & 77 & 119,3247 & 15,47531 \\
\hline
\end{tabular}

Dari tabel diatas dapat diketahui banyaknya data dari kategori jenis kelamin yaitu 42 subjek penelitian berjenis kelamin perempuan dan 77 subjek penelitian berjenis kelamin laki-laki.selanjutnya dapat diketahui nilai rata-rata tertinggi dari masing-masing variabel, bahwa nilai rata-rata tertinggi untuk variabel kesadaran diri ada pada subjek perempuan dengan nilai mean sebesar 123,64 dan nilai rata-rata tertinggi pada variabel kedisiplinan belajar ada pada jenis kelamin perempuan dengan nilai mean sebesar 120.0238.

Selanjutnya dilakukan kategori pengukuran kesadaran diri pada subjek penelitian dibagi menjadi tiga, yaitu kategori tinggi, sedang dan rendah yang dijabarkan pada tabel dibawah ini. 
Saroji ${ }^{1}$, Neni Widyayanti ${ }^{2}$, Roy Gustaf Tupen $\mathrm{Ama}^{3}$

Tabel 2. Kategorisasi skor kesadaran diri

\begin{tabular}{ccccc}
\hline Kategori & Norma & Skor & $\boldsymbol{\Sigma}$ & \% \\
\hline Tinggi & $\mathrm{X}>(\mu+1 \sigma)$ & $\mathrm{X}>132.25002$ & 21 & $17,6 \%$ \\
\hline Sedang & $(\mu-1 \sigma) \leq \mathrm{X} \leq(\mu+$ & $103,26682 \leq \mathrm{X} \leq$ & 84 & $70,6 \%$ \\
& $1 \sigma)$ & 132.25002 & & \\
\hline Rendah & $\mathrm{X} \leq(\mu-1 \sigma)$ & $\mathrm{X} \leq 103,26682$ & 14 & $11,8 \%$ \\
\hline & Total & & 119 & $100 \%$ \\
\hline
\end{tabular}

Berdasarkan tabel 2 diatas menunjukkan bahwa siswa SMK X Magelang memiliki kedisiplinan belajar kategori tinggi sebanyak 14 siswa $(11,8 \%)$, siswa yang memiliki kategori sedang sebanyak 84 siswa $(70,6 \%)$ dan siswa yang memiliki kategori rendah sebanyak 21 siswa $(17,6 \%)$. Jadi, dapat disimpulkan bahwa kecenderungan kedisiplinan belajar siswa SMK X Magelang berada pada kategori sedang yaitu sebanyak $84(70,6 \%)$ dari sampel yang berjumlah 119 siswa.

Selanjutnya pada variabel kedisiplinan belajar juga dilakukan pengukuran kateogri subjek yaitu kategori tinggi, sedang dan rendah yang dapat dilihat pada tabel dibawah ini.

Tabel 3. Kategorisasi skor Kedisiplinan belajar

\begin{tabular}{ccccc}
\hline Kategori & Norma & Skor & $\boldsymbol{\Sigma}$ & \% \\
\hline Tinggi & $\mathrm{X}>\mu+1 \sigma$ & $\mathrm{X}>134,81717$ & 22 & $18,5 \%$ \\
\hline Sedang & $\mu-1 \sigma \leq \mathrm{X} \leq \mu+1 \sigma$ & $\begin{array}{c}104,32563 \leq \mathrm{X} \leq \\
134,81717\end{array}$ & 76 & $63,9 \%$ \\
\hline Rendah & $\mathrm{X} \leq \mu-1 \sigma$ & $\mathrm{X} \leq 104,32563$ & 21 & $17,6 \%$ \\
\hline & Total & 119 & $100 \%$ \\
\hline
\end{tabular}

Tabel 3 diatas menunjukkan bahwa siswa SMK X Magelang memiliki kedisiplinan kategori tinggi sebanyak 21 siswa (17,6\%), siswa yang memiliki kategori sedang sebanyak 76 siswa $(63,9 \%)$ dan siswa yang memiliki kategori rendah sebanyak 22 siswa $(18,5 \%)$. Jadi, dapat disimpulkan bahwa kecenderungan kedisiplinan belajar siswa SMK X Magelang berada pada kategori sedang yaitu sebanyak $76(63,9 \%)$ dari sampel yang berjumlah 119 siswa.

Hasil uji normalitas menunjukan bahwa pada variabel kesadaran diri sebesar 0,713 dengan taraf signnifikansi sebesar 0,690 ( $\mathrm{p}<0,05)$ dan variabel kedisiplinan belajar sebesar 0,791 dengan taraf signifikansi sebesar $0,559(\mathrm{p}>0.05)$ sehingga sebaran skor kesadaran diri dan kedisiplinan belajar berada dalam sebaran normal yang dijabarkan pada tabel dibawah ini.

Tabel 4. Hasil Uji Normalitas

\begin{tabular}{lcccc}
\hline Variable & $\begin{array}{c}\text { Koefisien } \\
\text { normalitas }\end{array}$ & Sig & P & Keterangan \\
\hline Kesadaran diri & 0,713 & 0,690 & $>0,05$ & Normal \\
\hline Kedisiplinan belajar & 0,791 & 0,559 & $>0,05$ & Normal \\
\hline
\end{tabular}

Pada uji liniearitas menunjukkan bahwa deviation from linearity yaitu lebih besar dari 0,05 atau 1,138 > 0.05 sehingga hubungan kedua variabel yaitu kesadaran diri dengan kedisiplinan belajar adalah linear dengan nilai kofisien $\mathrm{F}$ sebesar 1,138 dan taraf signifikansinya sebesar 0,135 , yang di muat pada tabel dibawah ini. 
Saroji ${ }^{1}$, Neni Widyayanti ${ }^{2}$, Roy Gustaf Tupen $\mathrm{Ama}^{3}$

COUNSENESIA Indonesian Journal of Guidance and Counseling $2(1)(2021): 1-9$

Tabel 5. Hasil uji Liniearitas

\begin{tabular}{lccc}
\hline \multicolumn{1}{c}{ Variable } & $\begin{array}{c}\text { Koefisien } \\
\text { linieritas }\end{array}$ & $\begin{array}{c}\text { Signifikansi } \\
\mathbf{p}>\mathbf{0 , 0 5}\end{array}$ & Keterangan \\
\hline $\begin{array}{l}\text { Kesadaran diri } \\
\text { * Kedisiplinan belajar }\end{array}$ & 1,138 & 0,135 & Linear \\
\hline
\end{tabular}

Selanjutnya dilakukan uji hipotesis kedua variabel yang kemudian hasil dijelaskan dalam tabel dibawah ini.

Tabel 6. Hasil Uji Korelasi Product Moment

\begin{tabular}{llll}
\hline Variabel & Nilai $\mathbf{r}_{\mathbf{x y}}$ & Sig. $(\mathbf{p}<\mathbf{0 , 0 0 5})$ & Keterangan \\
\hline $\begin{array}{l}\text { Kesadaran Diri } \\
* \text { Kedisiplinan Belajar }\end{array}$ & 0.760 & 0,000 & Signifikan \\
\hline
\end{tabular}

Hasil uji hipotesis diatas menunjukkan koefisien korelasi (pearson correlation) sebesar 0,760 dan taraf signifikansi sebesar 0,000. Koefisien korelasi tersebut lebih besar dari 0.5 ( $p>0.5)$ dan taraf signifikansi (2-tailed) lebih kecil dari $0.005(\mathrm{p}<0.05)$ sehingga dapat dikatakan bahwa korelasi antara kesadaran diri dengan kedisiplinan belajar sangat kuat.

\section{Hubungan Antara Kesadaran Diri Dengan Kedisipinan Belajar Pada Siswa SMK "X" Magelang.}

Berdasarkan dari berbagai tahap analisis statistik di atas, maka hasil tersebut dapat menjawab hipotesis peneliti sebelumnya bahwa "Ada hubungan positif yang signifikan antara kesadaran diri dengan kedisiplinan belajar pada siswa SMK X Magelang”. Hasil dari perhitungan statistik menunjukkan bahwa terdapat hubungan positif yang signifikan antara kesadaran diri dengan kedisiplinan belajar pada siswa SMK X Magelang. Sehingga hipotesis dalam penelitian ini dinyatakan diterima. Hasil penelitian diatas sejalan dengan penelitian yang dilakukan oleh Niswah (2015) tentang hubungan antara persepsi hukuman dan self awareness dengan kedisiplinan belajar siswa di pondok pesantren Darul Ma'rifat cabang Gontor 3 Gurah Kabupaten Gurah Kediri diperoleh hasil bahwa terdapat hubungan yang positif antara persepsi hukuman dan self awareness dengan kedisiplinan belajar.

Penelitian yang dilakukan oleh Sudarmono, Apuanor, \& Kurniawati (2017) tentang pengaruh kesadaran diri terhadap kedisiplinan belajar Siswa Kelas IX SMPN 9 Sampit diperoleh hasil bahwa terdapat hubungan yang signifikan antara kesadaran diri dengan kedisiplinan belajar. Mumpuni (2017) dalam penelitianya tentang hubungan self awareness dengan kedisiplinan peserta didik kels IV di MI Annur Deyangan Mertoyudan Magelang diperoleh hasil bahwa terdapat hubungan yang signifikan antara self awareness dengan kedisiplinan. Penelitian yang sama juga dilakukan oleh Mustafida (2016) tentang Pengaruh kesadaran diri dan motivasi diri terhadap kedisiplinan siswa di MTs Ma'arif Sukosari diperoleh hasil bahwa ada hubungan yang signifikan antara kesadaran diri terhadapan kedisiplinan siswa.

Self awareness perlu dimiliki agar siswa menyadari apa yang terjadi selama proses pembelajaran sehingga dapat memahami setiap aturan dan belajar yang diterapkan (Romlah, 2013). Seseorang dengan kesadaran diri yang baik akan lebih memahami emosi, kelemaham dan keterbatasan diri serta pengenalan diri secara mendalam. Kesadaran diri sangatlah penting, memahami diri bukan hanya salah satu syarat agar kita sukses, tetapi juga merupakan syarat agar kita dapat bekerja bersama orang lain secara efektif (Mudana, 
2014). Self awareness berguna dalam mengetahui apa yang sedang kita rasakan dan menggunakannya untuk memandu pengambilan keputusan diri sendiri, memiliki tolak ukur yang realistis atas kemampuan diri dan kepercayaan diri yang kuat. Seseorang dikatakan memiliki kesadaran diri jika dia mampu memahami emosi yang sedang dirasakan, kritis terhadap informasi mengenai diri sendiri, dan sadar tentang diri sendiri secara nyata. Secara singkat, kesadaran diri dapat diartikan sebagai suatu sikap sadar seseorang mengenai pikiran, perasaan, dan evaluasi diri yang ada dalam dirinya sendiri. (Goleman, 2016).

Pentingnya siswa memiliki kesadaran yang tingi dalam meningkatkan kedisiplinan belajar, hal ini menunjukan bahwa untuk menciptakan perilaku disiplin dalam belajar harus dimulai dari dalam diri sendiri dengan adanya kesadaran diri yang tinggi. Dengan disiplin belajar yang muncul karena adanya kesadaran diri yang kuat, maka siswa dapat berhasil mencapai prestasi dan hasil belajar yang cemerlang. Sebaliknya siswa yang kerap kali melanggar peraturan sekolah pada umumnya akan berpengaruh kurang baik terhadap hasil dan prestasi belajar.

Hasil penelitian ini juga menunjukkan sebagian besar sampel mempunyai kesadaran diri yang sedang sebesar 70,6\% dan kedisiplinan belajar dengan kategori sedang sebesar 63,9\%. Variabel kesadaran diri memberikan sumbangan efektif sebesar 57,7\% terhadap kedisiplinan belajar dan sisanya merupakan faktor lain yang tidak diteliti dalam penelitian ini yang mempengaruhi kedisiplinan belajar. Faktor-faktor tersebut adalah faktor ekternal seperti pola asuh orangtua dan lingkungan sekolah.

Santrock ( 2007) menambahkan bawasannya ketika orang tua memperkenalkan pada aturan dan norma yang berlaku dan mendekatkan anak dengan nilai-nilai moral yang berlaku maka anak akan menjadi terbiasa dengan peraturan tersebut namun orangtua tidak boleh menjadi orangtua yang posesif. Hubungan orang tua dan anak mempengaruhi perkembangan moral anak. Lingkungan keluarga memiliki peran penting dalam hal memberikan pola asuh (Hurlock, 2013). Orang tua harus dapat memberikan pola asuh yang tepat sesuai dengan perkembangan anaknya dengan pola asuh yang tepat dan baik maka kedisiplinan belajar akan semakin tinggi yang kemudian implementasinya dalam perilaku belajar siswa di sekolah yang positif.

Disekolah peran guru juga sangat penting, khususnya peran guru konseling dalam menjalankan dan menanamkan perilaku disiplin bagi siswa-siswi yang mengalami permasalahan kedisiplinan belajar. Peran Guru tidak hanya sebagai pengajar namun sebagai konselor dalam meningkatkan disiplin siswa di sekolah dapat dilakukan salah satunya dengan cara meningkatkan pemahaman siswa tentang disiplin sekolah. Sebagai profesi yang hadir untuk merespon kebutuhan individu dalam memahami diri, lingkungan, serta hal lain yang terkait dengan kehidupannya dalam hal ini khususnya Guru BK dapat memberikan layanan bimbingan dan konseling dapat memfasilitasi upaya pengembangan dan /atau penyelesaian problematika disiplin siswa. Peningkatan kedisiplinan siswa tersebut dapat diwujudkan konselor melalui aplikasi pada berbagai jenis layanan bimbingan dan konseling, baik yang bersifat individual, kelompok, klasikal maupun kolaboratif yang kemudian hal ini akan membuat siswa semakin memiliki kesadaran diri yang tinggi yang implikasinya guna meningkatkan pemahaman akan pentingnya perilaku disiplin belajar. (Agustina,Daharni \& Hariko, 2019).

Esmiati dkk (2020) menjelaskan bahwa dalam pengembangan karakter khususnya perilaku disiplin dalam belajar, harus adanya kolaborasi kerjasama antara keluarga atau orangtua peserta didik. Posisi dan peran keluarga tidak sekedar formalitas semata namun memiliki andil besar dalam menamamkan nilai-nilai disiplin. Orang tua dan 
sekolah perlu membuat kesepakatan nilai-nilai utama apa yg perlu dibelajarkan, misalnya nilai-nilai kebaikan yang perlu dihayati dan dibiasakan dalam kehidupan peserta didik agar tercipta kehidupan yang harmonis, di sekolah,keluarga dan masyarakat. Nilai-nilai tersebut antara lain kejujuran, cinta kasih, pengendalian diri, saling menghargai/menghormati, kerjasama, tanggunggjawab, dan ketekunan, yang kemudian dari nilai-nilai inilah siswa akan semakin memiliki kesadaran diri yang tinggi dalam meningkatkan perilaku disiplin dalam belajar. Dengan demikian adanya kesadaran diri yang tinggi yang dimiliki oleh siswa-siswi SMA X Magelang akan dapat meningkatkan perilaku disiplin siswa guna mencapai kesusksesan akademik.

\section{PENUTUP}

Berdasarkan hasil penelitian dan pembahasan analisis data, diperoleh kesimpulan bahwa terdapat hubungan positif yang signifikan antara kesadaran diri dengan kedisiplinan belajar siswa SMK "X" Magelang yang berarti bahwa hipotesis dalam penelitian ini diterima. Hasil penelitian ini juga menunjukan sebagian besar sampel mempunyai kesadaran diri yang sedang 70,6\% dan kedisiplinan belajar dengan kategori sedang sebesar $63,9 \%$. Variabel kesadaran diri memberikan sumbangan efektif sebesar 57,7\% terhadap kedisiplinan belajar dan sisanya merupakan faktor lain yang tidak diteliti dalam penelitian ini yang mempengaruhi kedisiplinan belajar. Saran untuk guru yaitu hendaknya memberi pengertian serta menindak tegas terhadap siswa yang melanggar dalam lingkungan sekolah maupun dalam kelas sehingga para siswa-siswi dapat terbentuk kedisiplinan belajar yang tinggi serta guru hendaknya meningkatkan kesadaran diri siswa-siswi akan pentinya kedisiplinan belajar dengan metode konseling individual ataupun pelatihan indoor yang menarik dan melibatkan siswa-siswi sehingga kesadaran diri siswa yang tadinya tergolong sedang bisa terus meningkat. Bagi orangtua agar bisa memiliki memiliki peranan yang tinggi dalam menumbuhkan kedisiplinan belajar siswa, sehingga orang tua bisa lebih menerapkan pola asuh yang tepat kepada siswa-siswi, memberikan perhatian penuh kepada siswa-siswi serta dukungan sehingga kedisiplinan belajar siswa tetap terjaga dalam proses belajar di sekolah secara optimal. Peneliti selanjutnya yang ingin meneliti dengan variabel tergantung yang sama hendaknya dapat memperhatikan faktor-faktor lain yang mempengaruhi dan berhubungan dengan variabel tergantung.

\section{DAFTAR PUSTAKA}

Agustina, L., Daharnis, D., \& Hariko, R. 2019. Peran Konselor dalam Meningkatkan Disiplin Siswa: Tinjauan Berdasarkan Persepsi Siswa. JURKAM: Jurnal Konseling Andi Matappa, 3(1). DOI: http://dx.doi.org/10.31100/jurkam.v3i1.266

Ardi \& Minal. 2012. Pengaruh Pemberian Hukuman Terhadap Disiplin Siswa Dalam Belajar. Jurnal Ekonomi dan Sosial. Vol. 8 (1) 61-71. DOI: 10.33751/jppguseda.v3i1.2017

Azwar, S. 2016. Reliabilitas dan Validitas. Yogyakarta: Pustaka Pelajar.

Depdiknas. 2003. UU RI Nomor 20 Tahun 2003. Tentang Sistem Pendidikan Nasional. Jakarta: Biro Hukum dan Organisasi Sekjen Depdiknas.

Esmiati, A. N., Prihartanti, N., \& Partini, P. 2020. Efektivitas Pelatihan Kesadaran Diri Untuk Meningkatkan Kedisiplinan Siswa. Jurnal Ilmiah Psikologi Terapan, 8(1), 85-95. DOI: https://doi.org/10.22219/jipt.v8i1.11052

Goleman, D. Kecerdasan Emosional. Terjemahan oleh T. Hermaya. 2016. Jakarta: PT Gramedia Pustaka. 
Hurlock, E.B. Psikologi Perkembangan: Suatu Pendekatan Sepanjang Rentang Kehidupan. Terjemahan Oleh Istiwidayati \& Soedjarwo. 1993. Edisi Kelima. Jakarta: Erlangga.

Khairiyaturrizkyah, K., \& Nuraeni, N. 2019. Hubungan Antara Pola Asuh Demokratis Dengan Disiplin Belajar Pada Siswa Di Sma Negeri 1 Labuapi. Realita: Jurnal Bimbingan Dan Konseling, 3(5).

Mudana., Nyoman, O., Ketut, D. \& Kadek, S. 2014. Penerapan Konseling Gestalt dengan Teknik Reframing Untuk Meningkatkan Kesadaran Diri dalam Belajar Siswa Kelas VIII A1 SMP Negeri 4 Singaraja Tahun Ajaran 2013/2014. e-journal Undiksa Jurusan Bimbingan Konseling,2(1). DOI: http://dx.doi.org/10.23887/jibk.v2i1.3922

Mumpuni, T. 2018. Hubungan Self Awareness Dengan Kedisiplinan Peserta Didik Kelas VI Di MI Annur Deyangan Mertoyudan Tahun 2018/2019. Artikel ini disajikan dalam Konferensi Nasional Ke-7 Asosiasi Program Pascasarjana Perguruan Tinggi Muhammadiyah, 23 -25 maret. Jakarta : Aisyiyah (APPPTMA)

Mustafida, I. M. 2016. Pengaruh Kesadaran Diri Dan Motivasi Diri Terhadap Kedisiplinan Siswa Di Mts Ma'arif Sukosari Tahun Pelajaran 2015/2016. Laporan Penelitian, tidak diterbitkan. Ponorogo: STAIN

Musungu, B. J., \& PGDE, M. 2014. The Place Of Punishment In The Efficient Causation Of Students' Discipline. International Journal of Education and Research, 2(9), 329-336.

Nawawi, H. 2012. Metode Penelitian Bidang Sosial. Yogyakarta: Gajah Mada University Press.

Niswah, K. 2015. Hubungan Natara Hukuman Dan Self Awareness Dengan Kedisiplinan Belajar Siswa Di Pondok Pesantren Darul Ma'rifat Cabang Gontor 3 Gurah Kabupaten Kediri. Laporan Penelitian, tidak diterbitkan. Surabaya: Prodi Psikologi UIN Sunan Ampel Surabaya.

Romlah, M,S. (2013) Pendekatan Brainstorming Teknik Round-Robin Untuk Meningkatkan Kemampuan Penalaran, Komunikasi Matematis Dan Self Awareness Siswa SMP. Laporan Penelitian, tidak diterbitkan. Jakarta : FKIP UPI.

Santrock, J. 2007. Perkembangan anak. Terjemahan Oleh Mila Rahmawati dan Anna Kusnan. Jakarta: Erlangga.

Sarwono, S, W. 2010. Psikologi Remaja. Rajawali pers : Jakarta.

Sudarmono, S., Apuanor, A., \& Kurniawati, E. H. K. 2019. Pengaruh Kesadaran Diri Terhadap Kedisiplinan Belajar Siswa Kelas IX Smpn 9 Sampit. Jurnal ilmu pendidikan. 5(2). DOI: https://doi.org/10.46822/paedagogie.v5i2.57

Sukmanasa, E. 2016. Hubungan Antara Disiplin Belajar Dengan Hasil Belajar Pada Mata Pelajaran Ilmu Pengetahuan Sosial. Jurnal Kreatif: Jurnal Kependidikan Dasar, 7(1). DOI: https://doi.org/10.15294/kreatif.v7i1.9363

Tu'u, T. 2004. Peran disiplin pada perilaku dan prestasi siswa. Jakarta :

Uno, H. 2008. Orientasi baru dalam psikologi pembelajaran. Jakarta:PT bumi aksara

Winkel ,W,S. \& Hastuti, S. 2004. Bimbingan dan konseling. Jakarta: Insititut pendidikan. 